\title{
The use of nested Polymerase Chain Reaction (nested PCR) for the early diagnosis of Histoplasma capsulatum infection in serum and whole blood of HIV-positive patients Uso da Reação em Cadeia da Polimerase aninhada (PCR aninhada) para o diagnóstico precoce da infecção pelo Histoplasma capsulatum no soro e no sangue total de pacientes HIV positivos
}

\author{
Katia Cristina Dantas ${ }^{1}$ \\ Adriana Pardini Vicentini Moreira ${ }^{3}$ \\ Gil Benard \\ Paulo Ricardo Criado ${ }^{7}$
}

\author{
Roseli S. Freitas ${ }^{2}$ \\ Marcos Vinicius da Silva ${ }^{4}$ \\ Cidia Vasconcellos ${ }^{6}$
}

\begin{abstract}
The aim of the study was to detect the rDNA sequences and their regions in Histoplasma capsulatum, which could be considered species-specific and used as a molecular method for this diagnosis by the technique of nested polymerase chain reaction (nested PCR), employing specific sequences (primers) for H. capsulatum: $18 \mathrm{~S}$ rDNA region (HC18), $100 \mathrm{kDa}$ (HC100) and the sequence 5.8 S-ITS rDNA (HC5.8). The PCR sequences HC18, HC100 and HC5.8 resulted in a specificity of $100 \%$. The molecular assays may increase the specificity, sensitivity and speed in the diagnosis of Histoplasmosis.

Keywords: AIDS-related opportunistic infections; Histoplasma; HIV seropositivity; Molecular diagnostic techniques; Polymerase chain reaction

Resumo: O objetivo do estudo consistiu em detectar seqüências no $\mathrm{ADNr}$ e as suas regióes no Histoplasma capsulatum, que pudessem ser consideradas espécie-específicas e usadas como método molecular para o diagnóstico pela técnica da reação em cadeia da polimerase aninhada ("nested PCR") com seqüências específicas ("primers") para H. capsulatum: regióes 18S ADNr (HC18), 100kDa (HC100) e a seqüência 5.8 S ADNr-ITS (HC5.8). A "nested PCR" com as seqüências HC18, HC100 e HC5.8 resultaram em $100 \%$ de especificidade. Os ensaios moleculares podem aumentar a especificidade, sensibilidade e rapidez na diagnose da Histoplasmose.

Palavras-chave: Histoplasma; Infecções oportunistas relacionadas com a AIDS; Reação em cadeia da polimerase; Soropositividade para HIV; Técnicas de diagnóstico molecular
\end{abstract}

Received on 29.05.2012.

Approved by the Advisory Board and accepted for publication on 04.06.2012.

* Study undertaken at the LIM 53 of the Hospital das Clínicas, Faculty of Medicine, University of São Paulo (HCFMUSP), the Adolfo Lutz Institute (IAL) and the Emílio Ribas Infectology Institute - São Paulo (SP), Brazil.

Conflict of interest: None

Financial funding: FAPESP funding No. 2009/50362-0.

Pharmacist. Doctor of Science awarded by the Faculty of Medicine of the University of São Paulo (FMUSP) - researcher in the Faculty of Medicine of the University of São Paulo (FMUSP) - São Paulo (SP), Brazil.

Master of Science awarded by the Faculty of Medicine of the University of São Paulo (FMUSP)- Researcher in the LIM 53 of the Hospital das Clínicas, Faculty of Medicine, University of São Paulo (HCFMUSP) - São Paulo (SP), Brazil.

Doctor of Microbiology and Immunology, degree awarded by the Federal University of São Paulo (UNIFESP) - Adolfo Lutz Institute - State Health Secretariat (IAL) - São Paulo (SP), Brazil.

Doctor, degree awarded by the Faculty of Medicine of the University of São Paulo (FMUSP) - Infectologist of the Emílio Ribas Infectology Institute - São Paulo (SP), Brazil.

Post-doctorate - Professor of the Dermatology Department of the Faculty of Medicine of the University of São Paulo (FMUSP) - São Paulo (SP), Brazil

Post-doctorate - Professor in the stricto sensu Postgraduate Course of the Faculty of Medicine, University of São Paulo (FMUSP) and at the Medical Welfare Insitute for State Public Employees (IAMSPE) - São Paulo (SP), Brazil.

Doctor of Science (Dermatology) awarded by the Faculty of Medicine of the University of São Paulo (FMUSP) - Doctor in the Dermatology Division of the Hospital das Clínicas, Faculty of Medicine of the University of São Paulo (HCFMUSP) - São Paulo (SP), Brazil. 
Histoplasmosis (HP) is caused by the fungus Histoplasma capsulatum, known as a leading indicator of HIV infection. In endemic areas HP is the first manifestation of AIDS in 50\%-70\% of patients, occurring in $2 \%-5 \%$ of patients in non-endemic areas. ${ }^{1}$ The high lethality, with a marked incidence of mucocutaneous lesions, may be similar to miliary tuberculosis, a frequently encountered pathology in Brazil, prompting doctors to assume that HP is the latter infection, without considering the signs of HP in the differential diagnosis, and therefore delaying the initiation of appropriate antifungal therapy. ${ }^{2,3}$

The methods used for diagnosis have low sensitivity and specificity and are therefore less efficient. This emphasises the need for implementing highly accurate and quick turnaround diagnostic techniques. Direct microscopic examination and culture on Sabouraud media are the gold standard method of diagnosis. Microscopic examination however requires a good level of expertise. The culture method is also very slow (up to 4 months) and hazardous (due to the presence of spores). The sensitivity of microscopic examination of fluids and tissues is too low. Serological techniques are significantly limited since serology is negative in up to $50 \%$ of immunosuppressed patients suffering from histoplasmosis, especially those with acquired immunodeficiency syndrome (AIDS). Furthermore, the test for antigen detection in urine and /or serum is not accessible in the majority of nonendemic areas. ${ }^{4}$ This study aimed to detect sequences in the rDNA and ITS regions of $H$. capsulatum $(H c)$, which can be considered species-specific and to create an enabling tool, such as molecular diagnostics.

In the study we obtained 40 samples of whole blood and serum from individuals with suspected histoplasmosis. These were subsequently grouped according to the clinical aspects of patients: Group I (GI): 12 patients co-infected with $H$. capsulatum / AIDS, Group II (GII): 8 patients with HP associated with other immunodeficiencies; Group III (GIII): 10 strains isolated from fungal lesions of patients; Group IV (GIV): 10 patients with AIDS and other infections; Group V (GV): 10 individuals not infected with HIV and with suspected pneumonia caused by bacteria; Group VI (positive control) consisted of 9 isolates of $H$. capsulatum from patients with/without AIDS. The analysis of samples from each group was performed by conventional methods (mycological, serological, molecular) using: (i) control strains (to establish the sensitivity of both the conventional laboratory techniques and molecular methods); (ii) mycological examination, direct microscopic examination stained by Giemsa'method; cultures in different media such as Sabouraud-Dextrose agar; Infusion heart-brain (DIFCO, Detroit, MI, USA); Agar tryptone soy agar (Oxoid,
London, England) incubated at $30^{\circ} \mathrm{C}$ and $35^{\circ} \mathrm{C}$, and growth of the pathogens for 60 days, and (iii) serological methods: double immunodiffusion (ID) and immunoblotting (IB) according to the modified method used by Davis et al. ${ }^{5}$ Molecular analysis was performed by nested PCR with specific sequences ("primers") for $H$. capsulatum: $18 \mathrm{~S}$ rDNA region (HC18), $100 \mathrm{kDa}$ (HC100) sequences, using a modified method of Bialek et al. and 5.8 S rDNA-ITS (HC5.8) sequence by the modified method of Fugita et al. ${ }^{6,7}$

The results of mycological GIEMSA staining were not conclusive enough to suggest HP in whole blood samples of patients in Groups I and IV, $40 \%$ of samples GI were isolated $H$. capsulatum (30\% in GII), but $H$. capsulatum was not isolated in groups IV and $\mathrm{V}$. The immunodiffusion analysis showed that patients in GI and II showed $20 \%$ and $40 \%$ of circulating anti $H$. capsulatum antibodies, while patients in GV and GIV showed no reactivity to species-specific antigen. Analysis of immunoreactivity by "immunoblotting" revealed that the GI (30\%) and GII (70\%) subjects showed reactivity to the fractions of $\mathrm{H}$ and $\mathrm{MH}$. capsulatum. Patients in the GIV and GV showed no reactivity to the fractions $\mathrm{H}$ and $\mathrm{M}$. The reaction of nested PCR in serum samples from GI showed positive in $87 \%$ (HC18), 92\% (HC100) and 95\% (HC5.8), and GII showed a positive result in 70\% (HC18), 85\% (HC100) and $90 \%$ (HC5.8). The whole blood samples of patients in GI showed a positive result in $89 \%$ (18S rDNA), 95\% (HC100) and 98\% (HC5.8), GII showed a positive result in 70\% (18S rDNA), 80\% (HC100) and 92\% (HC5.8). Evaluation of nested PCR showed greater sensitivity in whole blood samples in relation to the serum. The results of the detection of $H$. capsulatum in serum and whole blood, by nested PCR G IV (AIDS and multiple infections), showed greater specificity to the sequence initiator HC5.8 (98\%, whole blood, 96\% - serum), followed by HC100 ( $97 \%$ - whole blood, 95\% - serum) and HC18S (90\% - whole blood, $88 \%$ - serum). The results of the analysis of nested PCR with the sequences (HC18, HC100 and HC5.8) in groups III (heterologous cultures), V (no other fungal infections, not HIV-positive) showed $100 \%$ specificity. The direct examination of GIEMSA stained samples can be suggestive but not conclusive. Despite the isolation of $H$. capsulatum, the whole blood samples to be considered evidence for the diagnosis of HP demonstrated low sensitivity in imunocompromised patients. The results obtained in mycological, serological and analyses of immunoreactivity demonstrated the need for molecular assays due to their higher specificity and sensitivity. This could be very suitable for the therapeutic monitoring of patients with pulmonary, cerebral and disseminated HP. $\square$ 


\section{REFERENCES}

1. Wheat J, Hafner R, Wulfson M, Spencer P, Squires K, Powderly W, et al. Prevention of relapse of histoplasmosis with itraconazole in patients with the acquired immunodeficiency syndrome. Ann Intern Med. 1993;118:610-6.

2. Maubon D, Simon S, Aznar C. Histoplasmosis diagnosis using a polymerase chain reaction method. Application on human samples in French Guiana, South America. Diagn Microbiol Infect Dis. 2007;58:441-4.

3. Kauffman CA. Histoplasmosis: a clinical and laboratory update. Clin Microbiol Rev. 2007;20:115-32.

4. Wheat LJ, Garringer, T, Brizendine E, Connolly P. Diagnosis of histoplasmosis by antigen detection based upon experience at the histoplasmosis reference laboratory. Diagn. Microbiol infect Dis. 2002;43:29-37.

5. Freitas RS, Carvalho-Vivi JO, Zamboni IM, Assis CM, Costa-Martins JE, VicentiniMoreira AP. The importance of serological assays in diagnosing acute pulmonary histoplasmosis. J Venom Anim Toxins Inct Trop Dis. 2009;15:278-88.

6. Bialek R, Feucht A, Aepinus C, Just-Nubling G, Robertson Vj, Knobloch J, et al. Evaluation of two nested PCR assays for detection of Histoplasma capsulatum DNA in human tissue. J Clin Microbiol. 2002;40:1644-7.

7. Fugita S, Senda Y, Nakaguchi S, Hashimoto T. Multiplex PCR Using Transcrebed Spacer 1 and 2 Regions for Rapid Detection and Identification of Yeast Strains. J Clin Microbiol. 2001;39:3617-22.

\author{
MAILING ADDRESS: \\ Paulo Ricardo Criado \\ Divisão de Dermatologia - Instituto Central \\ Av. Dr. Enéas de Carvalbo Aguiar, 255 \\ Cerqueira César \\ 05403000 São Paulo, SP. Brazil. \\ E-mail:prcriado@uol.com.br
}

How to cite this article: Dantas KC, Freitas RS, Moreira APV, Da Silva MV, Benard G, Vasconcellos C, Criado PR. The use of nested Polymerase Chain Reaction (nested PCR) for the early diagnosis of Histoplasma capsulatum infection in serum and whole blood of HIV-positive patients. An Bras Dermatol. 2013;88(1):141-3. 